scope of practice afforded pharmacists is well beyond their scope of expertise and affects [physician] practice."

No quick fix: The 2004 First Ministers Accord did not provide a "fix for a generation," report $67 \%$ of respondents to a survey of members in the Association of Canadian Academic Healthcare Organizations. The association of 40 teaching hospitals, regional health authorities and research institutes released its survey, completed by 29 of its 43 member presidents and CEOs, in July. A majority of executives ( $58 \%$ ) believe wait times will either stay the same or worsen in the next $3-5$ years as a result of measures in the accord.

Northern exposure: An Ontario Medical Association survey of Northwestern Ontario physicians and their spouses/partners indicates that nearly one-third of them plan to leave for less remote practices over the next 5 years. Some $18 \%$ of doctors now practising in Thunder Bay are making long-term plans to move, while $44 \%$ of those practising outside the northern city intend to leave their current community. The survey indicates doctors have few complaints about the nature of their practices, other than an excessive amount of work, or their remuneration. They feel far more dissatisfaction about community, family and cultural factors, such as ease of travel in and out of a community. "Income alone is not sufficient to retain physicians in Northwestern Ontario over the long term," the study argues. "Things that would improve retention were perceived to be: improving quality of life and educational/cultural opportunities for children; better employment opportunities for spouses/partners; more access to extended family (e.g., aging parents, siblings or adult children); physician having more time away from work to spend with the family; better orientation to their new community on arrival; and feeling more appreciated by the community." - Compiled by Barbara Sibbald and Wayne Kondro, CMAJ

DOI:I0.1503/cmaj.06II34
PULSE

\section{Government health care}

outlays fall below OECD

\section{average}

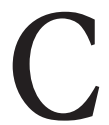

anadians have been asked to dig deeper into their own pockets to pay for private health insurance than their typical counterparts among other Organisation for Economic Co-operation and Development nations, according to the OECD's annual health data statistics.

Out-of-pocket payments and private insurance constituted $30 \%$ of Canadian health care spending in 2004 , some 3 percentage points higher than the OECD average of $27 \%$. Private insurance covers $13 \%$ of the Canadian health care bill, well above the OECD average of $6.5 \%$. But out-of-pocket outlays account for $15 \%$ of Canadians' overall health bill, below the OECD average of $20 \%$.

The disparity between Canadians and most of their OCED counterparts is most pronounced with respect to outlays for drugs. Private payments now constitute $62 \%$ of Canada's overall drug bill, as opposed to an OECD average of $39 \%$. Canada's rate falls below Mexico and the United States $(88 \%$ and $76 \%$, respectively), but well above that of Ireland (the lowest, at II\%).

The OECD data also indicate that over the past 15 years, Canadian governments have been slowly offloading the burden of health care expenses onto private shoulders (Table I). The public share of total health expenditures is now $69.8 \%$, as compared to $74.5 \%$ in I990. Moreover, Canada's public outlays now fall below the OECD average of $71.6 \%$.

Canadian Institute for Health Information Vice-President Jean-Marie Berthelot says the shift is most pronounced with respect to private insurance payments.

"There has been a significant increase in Canada," from about $8.1 \%$ in the early 1990 s to nearly $13 \%$ in 2004 .
Table 1: Public share of total health expenditures in OECD countries

$\%$ of total expenditures on health

\begin{tabular}{lcc} 
& & \\
\cline { 2 - 3 } Country & 1990 & 2004 \\
\hline Australia & 67.1 & - \\
\hline Austria & 73.5 & 70.7 \\
\hline Belgium & - & - \\
\hline Canada & 74.5 & 69.8 \\
\hline Czech Republic & 97.4 & 89.2 \\
\hline Denmark & 82.7 & - \\
\hline Finland & 80.9 & 76.6 \\
\hline France & 76.6 & 78.4 \\
\hline Germany & 76.2 & - \\
\hline Greece & 53.7 & 52.8 \\
\hline Hungary & - & 72.5 \\
\hline Iceland & 86.6 & 83.4 \\
\hline Ireland & 71.9 & 79.5 \\
\hline Italy & 79.1 & 76.4 \\
\hline Japan & 77.6 & - \\
\hline Korea & 38.5 & 51.4 \\
\hline Luxembourg & 93.1 & 90.4 \\
\hline Mexico & 40.4 & 46.4 \\
\hline Netherlands & 67.1 & 62.3 \\
\hline New Zealand & 82.4 & 77.4 \\
\hline Norway & 82.8 & 83.5 \\
\hline Poland & 91.7 & 68.6 \\
\hline Portugal & 65.5 & 71.9 \\
\hline Slovak Republic & - & - \\
\hline Spain & 78.7 & 70.9 \\
\hline Sweden & 89.9 & 84.9 \\
\hline Switzerland & 52.4 & 58.4 \\
\hline Turkey & 61.0 & 72.1 \\
\hline United Kingdom & 83.6 & 85.5 \\
\hline United States & 39.7 & 44.7 \\
\hline Average & 72.8 & 71.6 \\
\hline
\end{tabular}

Note: $\mathrm{OECD}=$ Organisation for Economic Cooperation and Development.

Source: OECD Health Data, June 2006.

By contrast, the OECD average has remained unchanged at $6.5 \%$ over the same time period, while in nations similar to Canada, like Australia, the rate has declined to $7.4 \%$ from $\mathrm{II} .4 \%$. - Wayne Kondro, CMAJ

DOI:Io.I503/cmaj.061046 